\title{
市販刺身の黄色ブドウ球菌による污染状況調查 ——平板培養法と増菌培養法での比較検討——
}

\author{
野村 秀一 ${ }^{* 1}$ - 原賀壮 勇*2 ・ 花木秀明 ${ }^{* 3}$ - 永山在明*2 \\ $(* 1$ 中村学園大学食物栄養学科, $* 2$ 福岡大学医学部微生物学教室, $* 3$ 順天堂大学医学部細菌学教室) \\ （受付 平成 13 年 9 月 21 日） \\ （受理 平成 14 年 5 月 28 日）
}

\section{Staphylococcus aureus Contamination of Commercial Slices of Raw Fish \\ - Comparison of Direct Plate Culture and Enrichment Culture -}

\author{
Shuichi Nomura ${ }^{* 1}$, Isao Haraga ${ }^{* 2}$, Hideaki Hanaki ${ }^{* 3}$ and Ariaki Nagayama*2 \\ $\left(^{* 1}\right.$ Department of Food and Nutrition, Nakamura Gakuen University, 5-7-1 Befu, \\ Jonan-ku, Fukuoka 814-0198) \\ (*2Department of Microbiology, School of Medicine, Fukuoka University, 7-45-1 Nanakuma, \\ Jonan-ku, Fukuoka 814-0180) \\ $\left({ }^{* 3}\right.$ Department of Bacteriology, School of Medicine, Juntendo University, 2-1-1 Hongo, \\ Bunkyo-ku, Tokyo 113-8421)
}

\begin{abstract}
緒言
ブドウ球菌食中毒は黄色ブドウ球菌によって産生され た毒素（エンテロトキシン）を食品とともに喫食するこ とによって発症する毒素型食中毒であり, 激しい吐き 気, 嘔吐, 下痢などを主症状とし, 発症率の高いのが特 徵である.この原因菌である黄色ブドウ球菌 (Staphylococcus aureus) は健康な七ト, 動物の鼻腔, 咽頭, 皮膚な ご, さらにこれらを取り巻く自然環境に広く分布し, 食 品を污染する機会も多く, 種々の食品から高率に検出さ れることが報告されている6). 本菌の各種食品における 污染状況の実態を把握することは, ブドウ球菌食中毒を 防止するうえからも重要である.

生食用魚介類である刺身はその特性からヒトの手で直 接処理加工されることから, 黄色ブドウ球菌の污染を受 ける機会が多いと考えられる。しかし, 黄色ブドウ球菌 は生食用魚介類の検査対象細菌ではないため, 生食用魚 介類の黄色ブドウ球菌の污染状況を調査した報告は少な い1,7). また, 黄色ブドウ球菌が検査対象となっている食 品における本菌の検出法は, 直接分離培養法である平板 培養法のみである. しかし, 腸炎ビブリオやサルモネラ などの主要な食中毒原因菌の検出法には選択増菌培養法

*1 昰814-0198 福岡市城南区別府 5-7-1

*2 要814-0180 福岡市城南区七隈 7-45-1

*3 焉113-8421 東京都文京区本郷 2-1-1
\end{abstract}

が実施されている，潮田ら ${ }^{4)}$ は黄色ブドウ球菌の検出法 に増菌培養法を取り入れることによって, 本菌の検出率 が平板培養法に比べて, 増加することを報告している.

これらのことから, 我々は市販刺身の黄色ブドウ球菌 による污染状況を把握するとともに, 検出法によって本 菌の検出率に違いがあるか否かを明らかにするために, 福岡市内のスーパーマーケットと鮮魚店から購入した刺 身について, 平板培養法と増菌培養法を用いて, 黄色ブ ドゥ球菌の污染状況について検討した。

\section{材料および方法}

\section{1. 検査材料}

1999 年 9 月から 11 月の 3 力月の間に福岡市内およ び近郊のスーパーマーケット (90 店舗) と鮮魚店 (90 店舗) で市販されているトレイパック詰めの刺身をそれ ぞれ 90 パック（1 店舗につき 1 トレイパック）購入し, 1 トレイパックを 1 検体として, 計 180 検体を供試し た. 刺身の種類はスーパーマーケットと鮮魚店でほぼ同 種で同数になるように購入した。 また, 刺身はすべて午 後 1 時から 5 時の間に購入し, 冷蔵保存して持ち帰り直 ちに実験に供した。

\section{2. 試料の調製法}

試料原液は刺身 $25 \mathrm{~g}$ をストマッカー用ポリエチレン バックに無菌的に秤量採取し， $0.1 \%$ ペプトン加滅菌生 理食塩水 $225 \mathrm{ml}$ を加えてストマッカー処理を行って調 
製した。

\section{3. 黄色ブドウ球菌の検出法}

1) 平板培養法：試料溶液の $0.1 \mathrm{~m} l$ を $3 \%$ 卵黄加 ンニット食塩寒天平板培地 (ニッスイ) に全面塗抹し, $37^{\circ} \mathrm{C}, 48$ 時間，マンニットを分解し, 卵黄反応陽性の集 落を黄色ブドウ球菌とした.

2) 増菌培養法：潮田 $5^{4)}$ の改良増菌培地を $50 \mathrm{~m} l$ 用 三角フラスコに $10 \mathrm{~m} l$ ずつ分注したものを作製しこれ に試料溶液 $10 \mathrm{ml}$ を加え, $37^{\circ} \mathrm{C}, 24$ 時間培養した。これ をよく擋拌し， 1 白金耳量を $3 \%$ 卵黄加マンニット食塩 寒天平板培地に塗抹し, 分離培養を行い, $37^{\circ} \mathrm{C}, 48$ 時間 培養後, マンニットを分解し, 卵黄反応陽性の集落を認 めたものを黄色ブドウ球菌陽性と判定した.

\section{4. 黄色ブドウ球菌の同定}

平板培養法および増菌培養法で得られたマンニット分 解，卵黄反応陽性を示した集落を平板培地より釣菌し た。この分離菌株について，アピスタフ（日本ビオメ リュー) 同定キットを用いて同定した。

\section{5. エンテロトキシンの産生性}

被検菌株を BHI ブイヨン培地 (Difco) $4 \mathrm{~m} l$ に接種し, $37^{\circ} \mathrm{C} ， 24$ 時間振とう培養後，培養液を遠心し（10,000 $\mathrm{rpm}, 5$ 分間), その上清について, ブドウ球菌エンテロ トキシン検出用キット，（A〜D 型, デンカ生研）を用い てエンテロトキシンの検出を行った.

\section{結果}

\section{1. 黄色ブドウ球菌の検出率の比較}

スーパーマーケットと鮮魚店から購入した刺身からの 黄色ブドウ球菌の検出率を平板培養法と増菌培養法で比 較検討した結果を Table 1 に示した.

平板培養法において，スーパーマーケットでは $6.7 \%$ (6/90), 鮮魚店では $50.0 \%(45 / 90)$ で, 本菌の全体とし ての検出率は $28.3 \%(51 / 180)$ であった。，一方，増菌培 養法においては，スーパーマーケットでは 33.3\%（30/ 90)で, さらに 24 検体が陽性となり, 鮮魚店では 90.0\% (81/90) で，さらに 36 検体が陽性となった．全 体としての検出率は $61.7 \%(111 / 180)$ で，60 検体が追 加陽性となり, 平板培養法に比べて 2.2 倍の検出率で あった．また，両培養法においても，黄色ブドウ球菌の 検出率はスーパーマーケットよりあ鮮魚店で販売されて いた刺身の方が高率であった。

\section{2. 黄色ブドウ球菌の污染菌数の比較}

平板培養法における污染黄色ブドウ球菌の菌数の比較 に执いて，スーパーマーケットでは 6 検体すべてが $1 \mathrm{~g}$ 当たり $10^{2}$ 個オーダーであった。鮮魚店では $1 \mathrm{~g}$ 当たり $10^{2}$ 個オーダーのあのが 33 検体, $10^{3}$ 個オーダーのあが 12 検体であった. 黄色ブドウ球菌による市販刺身の污 染菌数はスーパーマーケットよりも鮮魚店で販売されて いた刺身が多かった

\section{3. エンテロトキシン産生性}

平板培養法のみによって検出した黄色ブドウ球菌 51 株について，エンテロトキシン産生性を検討した結果を Table 2 に示した，全体として，51 株中 25 株 (49.0\%) がエンテロトキシンを産生した. スーパーマーケットで は 6 株中 6 株 (100.0\%) すべてが産生し，A 型 4 株，B 型 1 株, A,C 型 1 株であった. また, 鮮魚店では 45 株中 19 株 (42.2\%) が産生し， A 型 12 株，B 型 3 株，C 型 2 株， A, C 型 2 株であった。

一方，平板培養法および増菌培養法によって検出した 黄色ブドウ球菌 111 株（増菌培養法によって追加された 株； 60 株）のエンテロトキシン産生性を Table 3 に示し た。 全体として，111株中 60 株 (54.1\%) がエンテロト キシンを産生した。スーパーマーケットでは 30 株中 18 株 (60.0\%) が産生し， A 型 9 株，B 型 6 株，C 型 2 株, $\mathrm{A}, \mathrm{C}$ 型 1 株であった。 また，鮮魚店では 81 株中 42 株 (51.9\%) 方産生し， A 型 24 株，B型 11 株，C 型 3 株, $\mathrm{A}, \mathrm{C}$ 型 4 株であった。増菌培養法でさらに陽性になっ た 60 株中 35 株 (58.3\%) がエンテロトキシンを産生し ており，A型 17 株，B型 13 株，C型 3 株，A，C型 2 株 であった. また，エンテロトキシン型別では A 型産生株 が最む多く 60 株中 38 株 (63.3\%) であった.

\section{考察}

生食用魚介類である刺身の黄色ブドウ球菌による污染 状況を 2 つの検出法, すなわち, 直接分離培養法である 平板培養法と增菌培養法を用いて比較検討した。

平板培養法における黄色ブドウ球菌の検出率は，スー パーマーケットでは $6.7 \%$ (6/90)，鮮魚店では $50.0 \%$ (45/90)であった。増菌培養法においては，スーパー マーケットでは $33.3 \%(30 / 90)$, 鮮魚店では $90.0 \%$ $(81 / 90)$ であり，増菌培養法において，平板培養法より あスーパーマーケットでは 5 倍, 鮮魚店では 1.8 倍, 検

Table 1. Detection of $S$. aureus in commercial slices of raw fish

\begin{tabular}{cccc}
\hline Method for isolation & Shop & Detection ratio & Total \\
\hline \multirow{2}{*}{ Direct plate culture } & Supermarket & $6 / 90(6.7 \%)$ & $51 / 180(28.3 \%)$ \\
& Fish shop & $45 / 90(50.0 \%)$ & \\
Enrichment culture & Supermarket & $30 / 90(33.3 \%)$ & $111 / 180(61.7 \%)$ \\
\hline
\end{tabular}


Table 2. Enterotoxin types of S. aureus isolated from slices of raw fish by direct plate culture

\begin{tabular}{cccccccc}
\hline \multirow{2}{*}{ Shop } & No. of strains & $\begin{array}{c}\text { No. of entero- } \\
\text { toxigenic }\end{array}$ & \multicolumn{6}{c}{ Enterotoxin type } \\
\cline { 5 - 9 } & strains (\%) & A & B & C & D & A.C \\
\hline Supermarket & $6 / 6$ & 100.0 & 4 & 1 & 0 & 0 & 1 \\
Fish shop & $19 / 45$ & 42.2 & 12 & 3 & 2 & 0 & 2 \\
\hline \multicolumn{1}{c}{ Total } & $25 / 51$ & 49.0 & 16 & 4 & 2 & 0 & 3 \\
\hline
\end{tabular}

Table 3. Enterotoxin types of $S$. aureus isolated from slices of raw fish

\begin{tabular}{cccrrrrr}
\hline \multirow{2}{*}{ Shop } & No. of strains & $\begin{array}{c}\text { No. of entero- } \\
\text { toxigenic }\end{array}$ & \multicolumn{6}{c}{ Enterotoxin type } \\
\cline { 4 - 8 } & strains (\%) & A & B & C & D & A.C \\
\hline Supermarket & $18 / 30$ & 60.0 & 9 & 6 & 2 & 0 & 1 \\
Fish shop & $42 / 81$ & 51.9 & 24 & 11 & 3 & 0 & 4 \\
\hline Total & $60 / 111$ & 54.1 & 33 & 17 & 5 & 0 & 5 \\
\hline
\end{tabular}

出率が増加した．全体としての検出率の比較では，平板 培養法は $28.3 \%$, 増菌培養法では $61.7 \%$ であり, 2.2 倍 の検出率の増加か認められた。ささらに，平板培養法で黄 色ブドウ球菌が陰性と判定された 129 検体から増菌培 養法により 60 検体が黄色ブドウ球菌陽性となった。 ま た，本菌の検出率はスーパーマーケットよりも鮮魚店で 販売されていた刺身が高かった．楠ら位は販生食用魚 介類における黄色ブドウ球菌の污染状況調査において, 黄色ブドウ球菌の増菌培養法を導入することによって, 平板培養法の検出率よりもその検出率が 5 7 倍に増加 したことを報告している。これらの結果は検査検体から 黄色ブドウ球菌を確実に検出するには平板培養法だけで は不十分であることを示唆している.

平板培養法による污染黄色ブドウ球菌の菌数の比較に おいては，スーパーマーケットでは 6 検体すべてが $1 \mathrm{~g}$ 当たり $10^{2}$ 個オーダーであったが，鮮魚店においては， 33 検体が $10^{2}$ 個オーダー, 12 検体が $10^{3}$ 個オーダーで あった. 小田 ${ }^{3)}$ は食品 $1 \mathrm{~g}$ 当たりの黄色ブドゥ球菌数の 評価において，黄色ブドゥ球菌の規格基準がない食品に ついては, 未(非)加熱食品では $1 \mathrm{~g}$ 当たり $10^{3}$ 個以上は 不適であるとしており, 鮮魚店で販売されていた刺身の うち 12 検体が生食用としては不適であることが明らか になった。また，市販されている刺身の黄色ブドウ球菌 による污染菌数は，スーパーマーケットよりも鮮魚店で 販売されている刺身の方が多い結果であった。これらの 結果は店舗様式における環境，設備，衛生管理，および 従事者の衛生知識などの違いに起因するものと考えられ る.

わが国でのブドウ球菌食中毒原因菌のエンテロトキシ ン型の大多数は $\mathrm{A}$ 型産生菌である ${ }^{2)}$. そこで，分離株の エンテロトキシン産生性について検討した。平板培養法 で分離された 51 株中 25 株 (49.0\%) がエンテロトキシ ンンを産生した。増菌培養法によってさらに分離された 60 株を合計すると全体で 111 株中 60 株 (54.1\%) が産 生株で，増菌培養法によってエンテロトキシン産生株の
検出率も増加した．また，エンテロトキシン産生株 60 株中 38 株 (63.3\%) がエンテロトキシン A 型を産生し ていた.

黄色ブドウ球菌による食中毒発生にはその菌数が $1 \mathrm{~g}$ 当たり $10^{6}$ 個以上必要とされていることから，市販刺身 が食中毒の原因になる可能性は極めて少ないと考えられ る. しかし, 今回の調査に扔いて, 市販刺身は黄色ブド ウ球菌によって高率に污染されており，さらにエンテロ トキシン A 型を産生する株が多いという結果であった。 これらのことを考虑すると，刺身の保存状態によっては 黄色ブドウ球菌の菌数が食中毒を発生させるに足る菌数 に増加し，刺身がブドウ球菌食中毒の原因食品になりう る可能性む十分に考えられることから, 刺身の冷蔵保存 の幑底をはじめとする十分な衛生管理の必要性が示唆さ れる。

楠ら1)はすし種や刺身を污染している黄色ブドウ球菌 はヒ卜由来であり，すし種や刺身の原材料から販売まで の処理過程における HACCP 対策において，黄色ブドゥ 球菌をヒト污染指標菌と位置づけコントロールすること により，一般細菌数や大腸菌群数を抑えることが可能で あり，より衛生的な食品を提供できるであろうと述べて いる. しかし，これらのことを実行するためには検查検 体から確実に黄色ブドウ球菌を検出する必要がある。 今 回の我々の平板培養法と増菌培養法による市販刺身から の黄色ブドウ球菌の検出率の比較において，平板培養法 で黄色ブドウ球菌が陰性と判定された 129 検体からさ らに 60 検体が増菌培養法によって陽性となったことか ら，検査検体から黄色ブドウ球菌を確実に検出するには 増菌培養法を実施する必要があると考えられる。

最近, 潮田 ${ }^{5)}$ は食品衛生にかかわる黄色ブドウ球菌検 索に増菌培養法を導入すべきであることを提言している が, 今回得られた結果から, 我々あより安全な食品を提 供するためには黄色ブドウ球菌が検查対象細菌であるか どうかにかかわらず，すべての食品において，本菌の検 出法として増菌培養法を導入すべきであると考える. 
20 日食微誌 Vol. 19 No. 12002

現在, 黄色ブドウ球菌の増菌培養用の培地組成に関す る規定はなく, 今回, 我々は潮田ら ${ }^{4)}$ の改良増菌培地を 用いて検討し, 高い検出率を得た。しかし, 増菌培養用 の培地の組成によってはさらに検出率を高めることがで きる可能性もあり，今後，培地組成のさらなる検討が必 要であると思われる.

\section{要 約}

スーパーマーケットと鮮魚店で市販されていた刺身 （180 検体）について, 黄色ブドウ球菌の污染状況を平板 培養法と増菌培養法の 2 つの検出法を用いて比較検討 した.

平板培養法において, 黄色ブドウ球菌は 180 検体から 51 検体 (28.3\%) が検出された。一方, 增菌培養法では 180 検体から 111 検体 (61.7\%) が検出され, 平板培養 法で黄色ブドゥ球菌が陰性と判定された 129 検体から, さらに 60 検体において黄色ブドウ球菌が検出された.

分離された黄色ブドゥ球菌 111 株中 60 株 (54.1\%) が エンテロトキシンを産生しており，その中で 60 株中 38 株 (63.3\%) がエンテロトキシン A 型を産生していた. また，増菌培養法でさらに検出された 60 株中 35 株 (58.3\%) がエンテロトキシン産生株であり, 増菌培養法 によってエンテロトキシン産生株の検出も増加した。

これらの結果は市販刺身が黄色ブドウ球菌によって高 率に污染されていること，さらに，黄色ブドウ球菌を検
体から確実に検出するには平板培養法だけでは不十分で あり, 増菌培養法が必要であることを示唆している.

\section{文献}

1) 楠 〈み子, 潮田 弘, 神真知子, 新井輝義, 岩谷美枝, 石上 武, 山田澄夫：東京都多摩地区に打引る市販生食 用魚介類の細菌污染調查成績 (1986-1996)。 日食微誌, 15, 161-165 (1998).

2）小田隆弘：ブドウ球菌食中毒の最近の動向. 食衛誌，39, J-179-185 (1994).

3）小田隆弘: 食品中の食中毒検查法 3 , 黄色ブドウ球菌. 防 菌防徵，29, 595-600 (2001).

4) 潮田 弘, 新井輝義, 神 真知子, 楠 く子子, 石上 武, 山田澄夫, 田村行弘：各種食品加ら黄色ブドウ球 菌の高感度迅速検出法の開発. 東京都衛生局学会誌，98, 250-251 (1997).

5）潮田 弘：黄色ブドゥ球菌の増菌培養について. 食衛誌, 41, J-335 (2000).

6）品川邦汎, 浅尾 努, 石橋正憲, 本 博之, 国田信治, 日 佐和夫：ブドウ球菌エンテロトキシンに関する研究 (2) 一各種食品におけるブドゥ球菌の分布及びェンテロトキ シン産生について一, 大阪府公衆衛生研究所研究報告 食品衛生編，第 4 号，97-101 (1973).

7) 安田勝彦, 川坂修亮, 藤井義文, 馬淵亚吉, 菱田祐二, 伊 藤靖之：中央卸売市場を流通するむき身のすしだ稀の 細菌污染状況について。食品衛生研究, 41, 57-62 (1991). 